\title{
Environmentální výchova hrou - výsledky dopravní kampaně pro děti "Oblékáme hada Edu"
}

\author{
Danuše Strnadová, Hana Brůhová Foltýnová, Radomíra Jordová
}

Envigogika 12 (1) - Recenzované články/ Reviewed articles

Publikováno / Published 23. 7. 2017

DOI : $\underline{10.14712 / 18023061.540}$

\begin{abstract}
Abstrakt
Článek představuje a shrnuje výsledky environmentálně dopravní kampaně v České republice s názvem "Oblékáme hada Edu". Jedná se o českou verzi evropské hry Traffic Snake Game, do které je Čr zapojena od roku 2014. Tato hra je cílená na děti z mateřských škol a 1 . stupně základních škol, které se hravou formou učí uvažovat o zdravotních a environmentálních dopadech volby jednotlivých druhů dopravních prostředků a jsou podporovány co nejvíce využívat $k$ cestám do školy udržitelné dopravní módy chůzi, jízdu na kole či koloběžce, veřejnou dopravu a prípadně společnou jízdu dětí z více rodin automobilem.

$\checkmark$ ČR se do této environmentálně-dopravní kampaně zapojilo od roku 2014 zatím 49 škol, z toho 12 opakovaně. Článek diskutuje hlavní faktory úspěchu a dopady této kampaně na způsoby cestování do školy jak během samotné kampaně, tak i tři týdny po kampani, a srovnává faktory ovlivňující dopady kampaně, jako jsou pravidelné opakování hry a vliv období, kdy se tato hra hraje (jarní versus podzimní termín). Článek končí diskusí a doporučeními pro další pokračování kampaně i v dalších letech.
\end{abstract}

\section{Klíčová slova}

dopravní vzdělávání; Oblékáme hada Edu; environmentální výchova hrou; základní školy; mateřské školy; snižování negativních vlivů automobilové dopravy

\section{Abstract}

The article presents and summarizes the results of the environmental campaign in the Czech Republic entitled "We Dress Up the Snake Eda". This is the Czech version of the European game Traffic Snake Game, which was joined by the Czech Republic in 2014. This game is aimed at children from kindergartens and 1st grade primary schools who in a playful way reflect the health and environmental impacts of choosing individual means of transport and are encouraged to make the most of sustainable transport decisions - walking, cycling or transport on scooters, public transport and, where appropriate, joint driving of children from several families by car.

In the Czech Republic, 49 schools have been involved in this environmental campaign since 2004, of which 12 have participated repeatedly. The article discusses the main success factors of this campaign, and its impacts on travel-to-school decisions, both during 
the campaign itself and three weeks after the campaign. The authors compare the factors influencing the campaign's impact, such as the regular repetition of the game, influence of the period when this game is played (spring versus autumn term). The article ends with discussions and recommendations for continuing the campaign in the coming years in the Czech conditions.

\section{Key words}

Transport education; Traffic Snake Game; environmental education by game; primary schools; nursery schools; reducing negative impacts of car traffic 


\section{Možnosti změny dopravního chování dětí školního a předškolního věku v rámci vzdělávacího procesu}

Dopravní výchova je na základních školách standardní součástí osnov. Témata dopravní výchovy jsou rozpracována $v$ Rámcových vzdělávacích programech pro základní $\mathrm{i}$ pro mateřské školy (MŠMT 2016), její hlavní těžiště však spočívá ve vzdělávání $k$ bezpečnému pohybu na ulicích, $v$ dopravním prostředku a $v$ dopravě, zatímco environmentální aspekty dopravy bývají často opomíjeny. $V$ učebních osnovách se neřeší motivace a důvody, proč by děti měly více využívat environmentálně příznivější druhy dopravy, výukový čas není běžně věnován ani komplikacím, které mohou děti a jejich rodiče zažít při plánování a realizaci cest do škol udržitelnými druhy dopravy (např. plánování intermodálních cest, bezpečná úschova kola po príjjezdu do školy apod.). Přesto však právě to, jaké dopravní návyky při volbě dopravního prostředku získají lidé již v dětském věku, výrazně ovlivňuje naše dopravní chování i v dospělosti (McDonald, 2005; Verhetsel a Witlox, 2006).

Panuje obecný konsensus, že ten, kdo rozhoduje o tom, jak budou děti cestovat, jsou rodiče (Zwerts et al., 2010), přičemž věk, kdy se děti osamostatní a začnou samy cestovat do školy, se stále prodlužuje (Pooley et al., 2005). Posun věku, kdy se děti začínají přepravovat samy, a tím i prodlužování období závislosti dětí na dospělých při přepravě, je jedním z faktorů, který posiluje volbu environmentálně méně příznivých dopravních prostředků (osobní automobily) na úkor chůze a cyklistiky. Dalšími faktory narůstajícího využívání automobilů pro přepravu dětí do školy jsou obavy z dopravní bezpečnosti, rostoucí dostupnost automobilů $v$ domácnostech včetně nárůstu počtu domácností se dvěma $\mathrm{i}$ více auty, narůstající náročnost životního stylu a velký počet mimoškolních aktivit, ale také socioekonomické charakteristiky, jako jsou snižující se počet osob v domácnosti, vzdálenost místa bydliště od školy, socio-ekonomický status rodiny, věk a pohlaví atd. (Shaw et al., 2013).

To, že děti stále méně cestují pěšky a na kole, má negativní dopad na zdraví dětí (Carver et al., 2011). Nízká fyzická aktivita přispívá ke vzniku kardiovaskulárních chorob, diabetu typu 2 a obezitě (Raitakari et al., 1994). Naopak prínosy aktivní dopravy (především cyklistiky a chůze) pro celou populaci jsou mnohé, kromě vyšší fyzické aktivity také snížení skleníkových plynů, méně hluku a dalších emisí z dopravy, nižší spotřeba fosilních paliv a více príležitostí pro sociální interakce a poznávání prostředí (Percer, 2009; Schwebel et al., 2012; Zeedyk a Wallace, 2003).

Dopravně-environmentální hra „Oblékáme hada Edu" přináší dětem nový pohled na jejich dopravní chování a volbu dopravního prostředku. Děti z mateřských a základních škol se hravou formou dozví o dopadech jednotlivých druhů dopravy na zdraví a životní prostředí a jsou motivované samy tyto druhy dopravy více využívat.

Učitelé jsou vedeni $\mathrm{k}$ tomu, aby hned $\mathrm{v}$ úvodu kampaně dětem vysvětlili, proč jsou udržitelné druhy dopravy (jako jsou vlaky, hromadná doprava jako celek, jízdní kola, chůze nebo kombinace všech těchto dopravních prostředků) důležité pro naši planetu a jak moc záleží na tom, jak se do školy nebo kamkoliv jinam přepravujeme. Už ve starších odděleních mateřských škol - zhruba ve věku pěti let - jsou děti schopny tyto informace vnímat a nechat se jimi pozitivně ovlivnit. A s tím tato hra pracuje.

Kampaň zprostředkovaně působí také na změnu dopravního chování rodičů, kteří doprovází své děti do školy a jsou motivováni začít přemýšlet o způsobu dopravy na své cestě do zaměstnání jinak než automaticky nasednout do automobilu stojícího před domem. $Z$ uvedeného důvodu jsou $k$ aktivní spolupráci na kampani přizváni také rodiče, aby své děti v kampani podpořili a umožnili jim cestovat do školy udržitelnou formou dopravy. 


\section{Jak kampaň funguje, metodika}

Hra „Oblékáme hada Edu" spočívá v motivování dětí ke změně svého dopravního chování na cestách do školy směrem k udržitelným způsobům dopravy. Děti se během hry snaží dosáhnout cíle, který si škola předem stanovila - zvýšení podílu udržitelných cest do školy o určité procento. Každá škola si nastavuje před startem hry svůj vlastní cíl podle svého uvážení tak, aby byl reálný a dosažitelný. Hra probíhá na každé škole standardně 10 po sobě následujících školních dní. Termín hry si mohou školy přizpůsobit svým potřebám. Jak jsou děti motivovány ke změně svého dopravního chování? Za cesty vykonané udržitelnými způsoby dopravy (pěšky, na kole, veřejnou dopravou nebo s využitím spolujízdy se spolužáky) dostávají samolepky, které poté lepí na velký plakát s dopravním hadem Edou. Když se jim podaři dosáhnout při lepení samolepek na dopravního hada některého z barevných symbolů - milníků (obvykle po dvou dnech hraní hry) - čeká na ně odměna (například delší přestávka, den bez domácích úkolů apod.). Jakmile se dětem podaří pokrýt celého dopravního hada samolepkami a dosáhnout tak cíle školy, je pro ně připravena větší odměna, kterou škola připraví. Tou může být například pěší nebo cyklistický výlet apod.

Obr. 1: Plakát pro školy zapojené do hry „Oblékáme hada Edu“

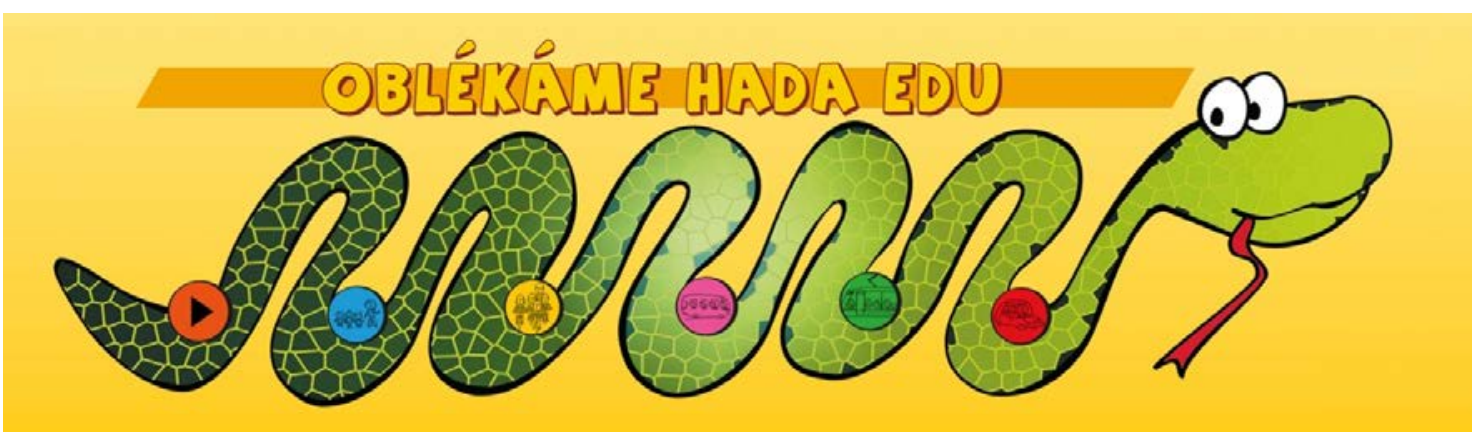

Zdroj: CDV, v.v.i. - materiály ke kampani „Oblékáme hada Edu“

Motivační je pro děti také týmová práce - společnými silami se snaží dosáhnout cíle a zvýšit podíl udržitelných cest do školy.

Cílovou skupinou kampaně jsou zejména děti od 4 do 12 let. Do kampaně v České republice se zapojily základní i mateřské školy. Nejvíce dětí zapojených do hry navštěvovalo v době jejího konání první stupeň základní školy (7220 žáků). V případě některých škol se do hry zapojily i děti navštěvující druhý stupeň ZŠ (1241 žáků ze 12 škol, např́klad ze ZŠ Meteorologická v Praze, ZŠ Šrámkova 4 v Opavě atd.).

Kampani předchází průzkum způsobů cestování dětí do školy, na jehož základě škola zjistí svou výchozí situaci a stanoví si cíl, kterého se bude snažit v kampani dosáhnout. Jako cíl hry si škola nastaví, o kolik procent se bude snažit zvýšit podíl udržitelných cest. Jak je uvedeno v metodice kampaně: „Dva týdny před začátkem hry provede každá škola jednodenní předběžný průzkum pomocí hlasování (zdvižením rukou). Učitelé tímto způsobem zjišt́ují a následně do formulářư zapisují aktuální způsoby dopravy do školy. Je potřeba zaznamenat všechny způsoby dopravy, včetně cest uskutečněných autem, aby bylo možné zjistit podíl cest udržitelnou dopravou. Na základě tohoto průzkumu před začátkem hry si každá škola stanoví své cíle." (CDV, 2015, p. 5). Obdobně probíhá průzkum způsobu cestování dětí do školy také během samotné hry. Děti dostávají každý den samolepky barevné „puntíky“ pokud cestují do školy udržitelným způsobem. Učitelé zapisují tyto cesty každý den do třídních hodnotících formulářů nebo přímo do webového formuláře. Tři 
týdny po skončení hry škola provede ještě poslední průzkum způsobů cestování do školy, jehož cílem je zjistit dlouhodobý vliv kampaně na změnu dopravního chování dětí. Podrobněji je metodika hry popsána v Manuálu pro učitele (CDV 2015). Po zadání dat ze škol do webového formuláře se výsledky automaticky vyhodnotí a jsou vygenerovány grafy, které zobrazují podíl jednotlivých druhů dopravy při cestách do školy. Mohou se tak porovnávat výsledky mezi zúčastněnými školami.

Celkové výsledky i výsledky jednotlivých škol jsou dostupné na webových stránkách kampaně (http://www.trafficsnakegame.eu/czechrepublic/hra/vysledky).

Školy zapojené do kampaně získávaly zdarma materiály pro hru (do konce roku 2016) a metodickou podporu Centra dopravního výzkumu, v.v.i. (dále CDV). Je již na vlastním uvážení jednotlivých škol a učitelů, zda a jak hru doplní o další vzdělávací aktivity a kampaně. Tzv. rozšířená verze hry, která spočivá v zorganizování dalších aktivit na podporu udržitelné dopravy a péče o životní prostředí (propojení s výukou na dopravním hřišti, přednáška s policií, jízda zručnosti na kole, sázení stromků, pěší výlet apod.), byla atraktivní hned pro několik škol. Navíc školy využily i možnost použít tuto hru a téma $v$ dalších vyučovacích předmětech. Například všechny zapojené pražské školy kampaní "Oblékáme hada Edu" navázaly na projekt "Bezpečné cesty do škol", kterého se účastnily $\checkmark$ predchozích letech a který byl zaměřený na zvyšování bezpečí dětí při cestách do školy (identifikování nebezpečných míst a návrh opatření k usnadnění pěších či cyklistických cest do školy, včetně realizace těchto opatření s podporou hlavního města Prahy).

Hra vznikla jako malý projekt pro několik škol v belgických Flandrech, odtud se rozšírila po celé Evropě pod názvem Traffic Snake Game (TSG). V začátcích této hry byl zaznamenán velký úspěch také $v$ Rakousku a Nizozemí. $V$ rámci následných evropských projektů pak byla tato hra rozšiřena do dalších zemí. $V$ průběhu tří let byla hrána $v$ Belgii, Bulharsku, Itálii, Mad'arsku, Nizozemí, Rakousku, Řecku, Slovinsku a ve Velké Británii. Do kampaní Traffic Snake Game se v těchto devíti zemích zapojilo téměř 85 tisíc žáků, pres 5 tisíc učitelů a více než 350 škol $^{1}$.

Obliba této vzdělávací hry v Evropě rychle roste. Podle průběžných výsledků se do ní zapojilo ve školním roce 2014/2015 téměř 50 tisíc dětí z 325 škol ze 169 měst a ve školním roce 2015/2016 přes 80 tisíc dětí z 549 škol z 267 měst. Kampaň probíhá v 19 evropských zemích včetně České republiky, Slovenska, Německa, Rakouska, ale např́klad i Rumunska a Bulharska. Celkem se do kampaně zapojilo 177587 žáků z 1192 škol v 507 městech ${ }^{2}$. Dohromady se podařilo ušetřit 397 tun emisí $\mathrm{CO}_{2}{ }^{3}$

\section{Zkušenosti se zapojováním škol v ČR}

$\checkmark$ České republice se hra setkala s velkým zájmem škol, jejich počet postupně narůstal, přičemž školy se dařilo zapojit jak přimým kontaktem koordinátorů z CDV s vedením škol, tak i díky spolupráci s politickými a dalšími zástupci měst, kteří podpořili a

\footnotetext{
${ }^{1}$ Více informací je $\mathrm{k}$ dispozici $v$ brožuře projektu $v$ angličtině na internetové stránce: http://www.schoolway.net/docs/CONNECT_booklet0.pdf

${ }^{2}$ Výsledky evropského projektu TSG $v$ letech 2014 - 2017 jsou dostupné na adrese:

http://www.trafficsnakegame.eu/wp-

content/uploads/2017/01/TSGNetwork_Infographic_2014_2017.pdf

${ }^{3}$ Další informace a seznam zapojených zemí je k dispozici na internetových stránkách TSG: http://www.trafficsnakegame.eu/countries/.
} 
prípadně i koordinovali tuto kampaň ve školách ve svém městě. Do kampaně se tak od jejího startu na podzim 2014 postupně zapojilo 49 škol, 12 z nich opakovaně.

Hra "Oblékáme hada Edu" je určena pro děti od 4 do 12 let, nejvíce se osvědčilo zapojení žáků 1 . stupně základní školy. Do hry se mohly zapojit jednotlivé třídy, školní družiny nebo i mateřské školy. Kampaň s hadem Edou v českém prostředí probíhá typicky na jaře nebo na podzim. Nejoblíbenějším obdobím, které si školy vybírají pro tuto kampaň, je podzim, kdy mohou hru spojit $s$ dalšími aktivitami v rámci Evropského týdne mobility (často i v koordinaci s aktivitami, které připravilo jejich město). Následující tabulka shrnuje počet zapojených škol a dětí v jednotlivých obdobích v letech 2014-2016.

Tabulka 1: Vývoj počtu zapojených škol a dětí v ČR za období září 2014 až prosinec 2016

\begin{tabular}{|l|c|c|}
\hline Období & Počet zapojených škol & Počet zapojených dětí \\
\hline Podzim 2014 & 13 & 2265 \\
\hline Jaro 2015 & 5 & 1232 \\
\hline Podzim 2015 & 14 & 2242 \\
\hline Jaro 2016 & 11 & 1545 \\
\hline Podzim 2016 & 25 & 5884 \\
\hline
\end{tabular}

Zdroj: CDV, v.v.i. - Databáze kampaně „Oblékáme hada Edu" (neveřejná databáze výsledků projektu)

Obr. 2: Mapa škol zaregistrovaných do kampaně Oblékáme hada Edu (podzim 2014 podzim 2016)

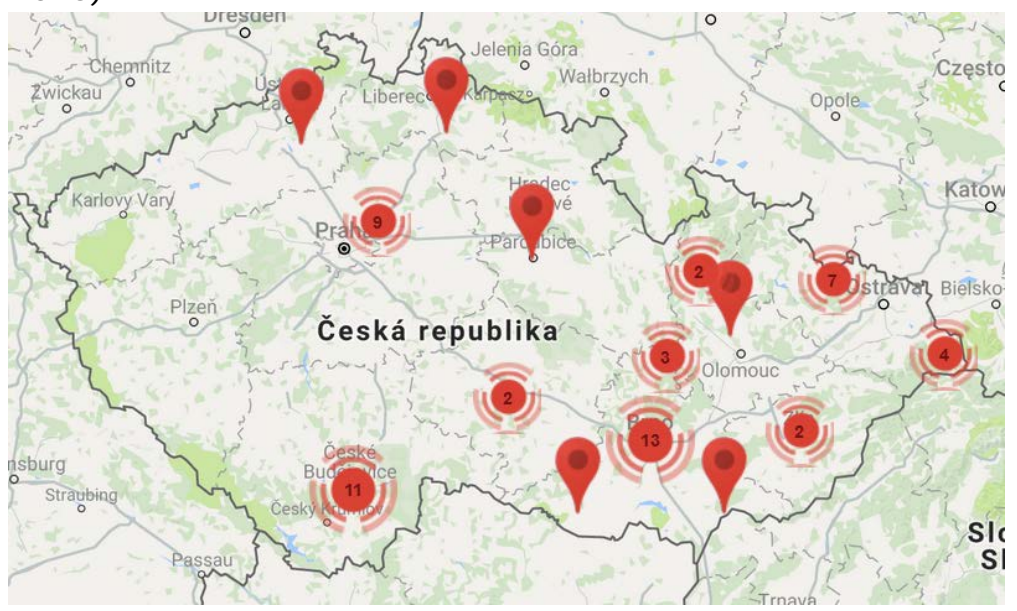

Zdroj: Webové stránky kampaně "Oblékáme hada Edu"

(http://www.trafficsnakegame.eu/czechrepublic/skoly)

Pozn.: Na obrázku jsou zachyceny i školy, které jsou zaregistrované, ale hru začnou hrát až v roce 2017.

Školy v České republice se zapojily do hry s různými cíli. Nejčastějším byla reakce na stávající dopravní situaci a zvýšení bezpečnosti v okolí školních budov, ale setkali jsme se i s motivací, jako je snaha podpořit zdravé životní prostředí v okolí školy, posílit aktivní 
pohyb dětí, mít pozitivní vliv na životní styl, samostatnost a bezpečnost žáků. Tyto cíle byly obdobné jako u škol v ostatních zapojených zemích.

Za všechny zúčastněné školy uvádíme pár př́íkladů, s jakými očekáváními se školy do hry přihlásily, co je motivuje:

- ZŠ a MŠ Křtiny (podzim 2016): „Chceme snižit počet žáků, které rodiče vozí autem až ke škole, a to zejména proto, že silnice vedoucí ke škole byla vyhodnocena jako velmi rizikové místo $z$ hlediska bezpečnosti dětí."

- ZŠ Opava, Šrámkova 4 (podzim 2016): „Do soutěže jsme se prihlásili, protože bezpečnost dětí klademe vždy na první místo a tato soutěž hravou formou děti upozorní na úskalí cesty do a ze školy."

- ZŠ a MŠ Otnice, okr. Vyškov (podzim 2016): „Dojíždějí k nám děti ze tří okolních vesnic. $V$ poslední době však přibývá zejména ráno před školou množství aut, kterými rodiče vozí žáky do školy. Zapojením do kampaně chceme podpořit zdravé životní prostředí v okolí školy a aktivní pohyb dětí. Zároveň chceme podporovat samostatnost a bezpečnost žáků, kteří do školy přicházejí sami, at' už pěšky, na kole či autobusy IDS JMK (Integrovaného dopravního systému Jihomoravského kraje)."

Velký podíl mezi zapojenými školami mají ty, které se již účastní některého programu zaměřeného environmentálně, na podporu bezpečné dopravy do školy nebo s tematikou zdraví. Jedenáct škol se zapojilo do mezinárodního programu Ekoškola, sedm škol do programu Škola podporující zdraví, šest škol realizovalo Bezpečné cesty do školy. Osm škol je zapojeno do programu Rodiče vítáni, který oslovuje školy otevřené partnerské komunikaci s rodiči. Tento zájem je pochopitelný, u škol zapojených do těchto programů se dá očekávat větší vnímavost i zájem o environmentální témata.

\section{Dopady hry na dopravní chování zapojených dětí a na životní pro- středí}

Ve většině zapojených škol došlo $v$ průběhu hry $k$ nárůstu podílu udržitelných cest při cestách do školy o několik procentních bodů, na mnoha školách však byl nárůst šetrného cestování do školy velmi výrazný. 21 škol zaznamenalo nárůst udržitelných cest o více než 15 procentních bodů, z toho některé opakovaně (ZŠ a MŠ Milíkov, ZŠ a MŠ Košařiska). 
Graf 1: Způsob dopravy žáků do školy před startem hry, v jejím průběhu a tři týdny po ukončení, období září 2014 - listopad 2016 (data za 49 škol a 8702 žáků)

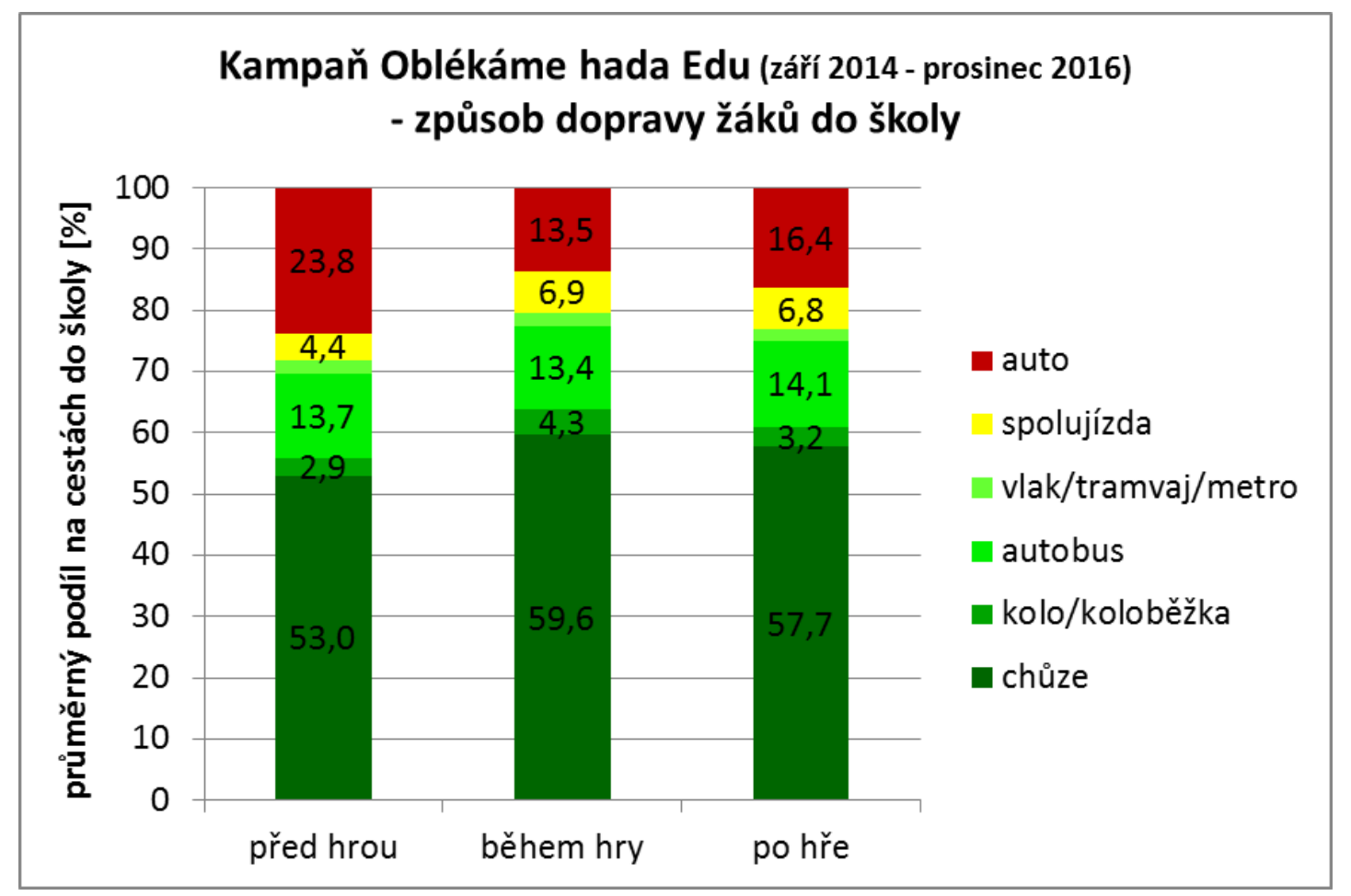

Zdroj: CDV, v.v.i. - Databáze kampaně „Oblékáme hada Edu" (neveřejná databáze výsledkü projektu)

Z grafu výše je zřejmé, že průměrný podíl udržitelných cest do školy byl vysoký již před startem kampaně, a to $76,2 \%$. Cesty dětí autem (individuálně s rodiči) činily pouze necelou čtvrtinu sledovaných cest do školy. Během kampaně vzrostl podíl cest do školy vykonaných aktivními způsoby dopravy (chůze, kolo/koloběžka) o 8 procentních bodů (z 55,9 \% na 63,9\%). Celkový podíl udržitelných cest během kampaně vzrostl o 10,3 procentních bodů a činil tak $86,5 \%$. Vliv kampaně na změnu dopravního chování dětí je zřejmý i tř̌i týdny po konci hry (vyšší podíl udržitelných cest o 7,4 procentních bodů na dělbě přepravní práce než před startem hry).

Výrazný vliv na změnu dopravního chování dětí při cestách do školy měla hra zejména ve venkovských školách. Před startem hry cestovalo na venkově v zapojených školách 68,3 \% dětí do školy udržitelným způsobem, v průběhu hry podíl udržitelných cest vzrostl o 17,7 procentních bodů na $86 \%$. Tři týdny po ukončení hry byl podíl udržitelných cest ve venkovských školách o 13 procentních bodů vyšší než před startem hry $(81,3 \%)$.

Na vyšší podíl cestování autem do školy na venkově má často vliv dojiždění rodičů do zaměstnání mimo obec (děti vozí ráno s sebou a vyloží je u školy, pak pokračují do práce mimo obec) a dojižd'ka do školy z okolních obcí. Na volbu dopravního prostředku pro cesty do školy může mít vliv také kvalitnější infrastruktura pro pěší a cyklisty ve městech oproti venkovu. Cestování do školy veřejnou dopravou se ukázalo jako srovnatelné na venkově i ve městech. Ve městech je však vyšší podíl chůze i jízdy na kole při cestách do školy. 
Graf 2: Výsledky kampaně Oblékáme hada Edu v jednotlivých zapojených školách na podzim 2016 (data za 4133 žáků a 25 škol)

\section{Výsledky kampaně Oblékáme hada Edu - podzim 2016}

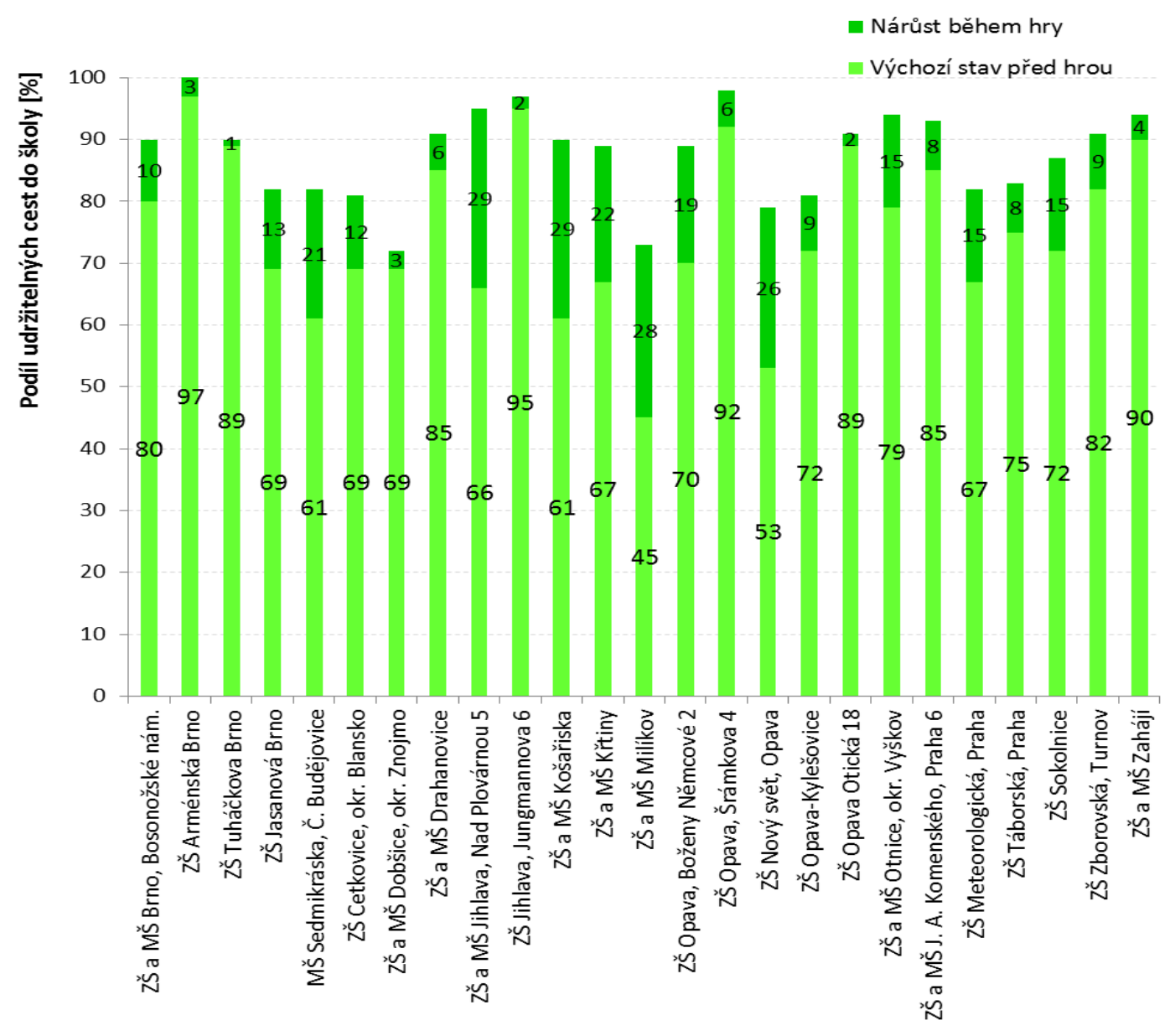

Zdroj: CDV, v.v.i. - Databáze kampaně „Oblékáme hada Edu" (neveřejná databáze výsledků projektu)

Ze škol, které se dosud do hry zapojily, mají největší podíl udržitelných cest „sídlištní školy ve velkých městech (uprostřed zástavby panelových domů/bytovek). Tyto školy se vyznačují především vysokým podílem chůze (nad $70 \%$ reportovaných cest), a to již před startem kampaně. Ze zapojených škol se jedná o ZŠ Arménská Brno, ZŠ a MŠ Kaštanová Třinec, ZŠ a ZUŠ Bezdrevská České Budějovice a ZŠ Bosonožská Brno ${ }^{4}$. Například ZŠ Arménská se nachází uprostřed panelového sídliště v Brně-Bohunicích a navštěvují ji děti z nejbližšího okolí. $V$ bezprostředním okolí školy není frekventovanější silnice, z dopravního hlediska se jedná o poměrně klidnou lokalitu. I to je zřejmě důvodem, proč byl již před

\footnotetext{
${ }^{4}$ Výsledky jednotlivých škol jsou dostupné online na webu: http://www.trafficsnakegame.eu/czechrepublic/skoly/
} 
startem hry TSG na podzim 2016 ve škole vysoký podíl udržitelných cest do školy (97 \%), který v průběhu hry ještě vzrostl na $100 \%$.

\section{Školy s největším nárůstem podílu udržitelných cest}

Největší změnu ve způsobu dopravy dětí do školy zaznamenala v průběhu kampaně ZŠ a MŠ Chudčice (okr. Brno-venkov). V této škole se na jaře 2016 zvýšil podíl udržitelných cest na cestách do školy o 45 procentních bodů. Společná jízda dětí autem do školy vzrostla o 33 procentních bodů, jízda na kole o 7 a později, tři týdny po konci hry, o další 2 procentní body. $V$ průběhu hry také vzrostl podíl chůze na cestách do školy o 3 procentní body a cestování autobusem o 2 procentní body.

V ZŠ a MŠ Kubatova v Českých Budějovicích vzrostl podíl udržitelných cest v průběhu hry na podzim 2014 o 37 procentních bodů. $V$ průběhu hry se zvýšil zejména podíl společné jízdy dětí autem do školy (spolujízda), a to o 16 procentních bodů. U chůze a u jízdy na kole byl zaznamenán nárůst o 10 procentních bodů u každého dopravního módu. Navíc škola zaznamenala tři týdny po konci hry velký nárůst podílu chůze na cestách do školy, ten vzrostl z 27 \% před kampaní a 37 \% v průběhu hry na hodnotu 70 \% tři týdny po konci hry. Podíl udržitelných cest do školy dosáhl v průběhu hry $90 \%$ a udržel se na této vysoké úrovni i po konci hry, jen 13 \% dětí zapojených do hry vyměnilo po konci hry cestování spolujízdou za chůzi.

ZŠ a MŠ Milíkov zaznamenala v průběhu hry na podzim 2015 nárůst udržitelných cest o 28 procentních bodů. Největší nárůst byl u chůze, a to z 28 \% před hrou na 53 \% v průběhu hry. Úspěch hry u dětí potvrzuje také zpětná vazba z této školy: „Žáci se do hry zapojili s nadšením, na jednu stranu vzájemně soupeřili, komu se podaří nasbírat nejvíce nálepek, a na druhou stranu se zase navzájem motivovali a domlouvali na společné chưzi do školy. Odměnou za snahu pak byla na závěr hra, při které žáci plnili různé druhy úkolư na dopravním hřišti u školy." Dalšími velmi úspěšnými školami byla ZŠ a MŠ Košařiska a ZŠ a MŠ Jihlava Nad Plovárnou, v nichž vzrostl podíl udržitelných cest v průběhu hry na podzim 2016 o 29 procentních bodů.

Také mateřské školy dosáhly v kampani poměrně velkého zvýšení podílu udržitelných cest, a to o 14 až 23 procentních bodů. Podíl udržitelných cest zůstal v MŠ U Pramene (České Budějovice) a v MŠ Budovatelská (Zlín) i tři týdny po konci hry vyšší oproti výchozí situaci před startem hry. Zajímavé je, že u škol, které hrály hru s hadem Edou na podzim, se podíl udržitelných cest po kampani snížil výrazněji než u škol hrajících na jaře.

Tabulka 2: Podíl cest do školy udržitelnými druhy dopravy u mateřských škol zapojených do hry

\begin{tabular}{|l|c|c|c|}
\hline Škola (termíny hry) & UC před hrou & UC během hry & UC po hře \\
\hline MŠ U Pramene, ČB (podzim 2014) & $39 \%$ & $62 \%$ & $49 \%$ \\
\hline MŠ Sedmikráska, ČB (podzim 2016) & $61 \%$ & $82 \%$ & $52 \%$ \\
\hline MŠ Budovatelská, Zlín (jaro 2015) & $55 \%$ & $69 \%$ & $65 \%$ \\
\hline
\end{tabular}

Pozn.: UC = cesty udržitelnými způsoby dopravy; ČB = České Budějovice

Zdroj: CDV, v.v.i. - Databáze kampaně „Oblékáme hada Edu" (neveřejná databáze výsledků projektu) 
Během kampaně se od jejího startu v záŕí 2014 do konce roku 2016 díky změně způsobů dopravy do školy a kilometrům automobilem, které tak nebyly ujety, ušetřilo $v$ ČR přibližně 11 tun emisí $\mathrm{CO}_{2}$. Výpočet byl učiněn pomocí nástroje MaxEva, který byl vytvořen $\checkmark$ evropském projektu MAX a dále rozvinut v projektu EPOMM-PLUS. ${ }^{5}$

Ve školním roce 2014/2015 se v průběhu kampaně ušetřilo 17630 kilometrů cest autem a 3 tuny emisí $\mathrm{CO}_{2}$, v následujícím školním roce bylo v průběhu hry ušetřeno 13 072 kilometrů cest automobilem a 2,2 tun emisí $\mathrm{CO}_{2}$. Podrobnější výsledky jsou k dispozici v evaluačních zprávách projektu TSG. ${ }^{6}$ Souhrnná data za školní rok 2016/2017 budou k dispozici v průběhu roku 2017. Vzhledem k výraznému nárůstu počtu škol zapojených do kampaně již v prvním pololetí 2016/2017 však očekáváme ještě výraznější úsporu kilometrů potenciálně ujetých automobilem i související snížení emisí $\mathrm{CO}_{2}$ než v předchozích ročnících kampaně.

\section{Faktory ovlivňující úspěch hry}

$\checkmark$ průběhu tří let, kdy se na našem území hra realizuje, se ukázalo, že kromě geografických faktorů (město $x$ venkov) a celkové filozofie školy jsou pro úspěch této kampaně důležité i další faktory, především: opakování hry, počasí během hry, spolupráce s místní samosprávou či dopravními odborníky a zapojení rodičů. Podívejme se na tyto faktory blíže.

\section{a) Opakování hry}

Opakování hry "Oblékáme hada Edu" (obvykle každý rok ve stejném období, tj. na jaře nebo na podzim) vede $k$ větší fixaci dětí pro volbu udržitelného dopravního prostředku. Ukazuje se, že většina škol, které hrají tuto hru opakovaně, vykazuje trend narůstajícího podílu cestování do školy udržitelnými způsoby dopravy (viz následující graf).

\footnotetext{
${ }^{5}$ Podrobnější informace o tomto evaluačním nástroji jsou dostupné na webu http://www.epomm.eu/maxeva.

${ }^{6}$ Evaluační zprávy za jednotlivé školní roky jsou k dispozici na webových stránkách projektu TSG: http://www.trafficsnakegame.eu.
} 
Graf 3: Podíl udržitelných cest u škol opakujících hru „Oblékáme hada Edu“ - srovnání jednotlivých kol hry ${ }^{7}$

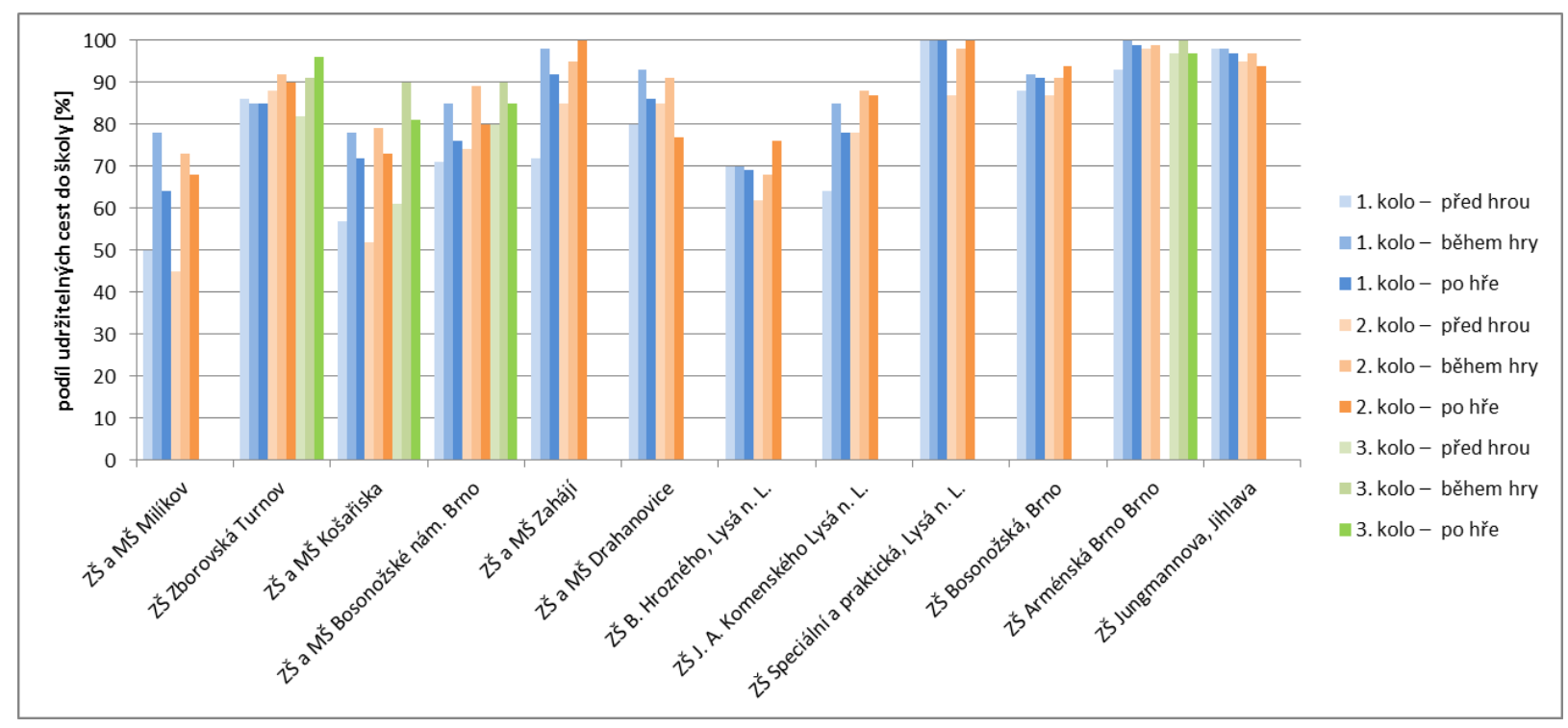

Zdroj: CDV, v.v.i. - Databáze kampaně „Oblékáme hada Edu" (neveřejná databáze výsledkü projektu)

U škol, které realizovaly kampaň opakovaně, se trend narůstajícího podílu udržitelných cest promítá $v$ dlouhodobém měřítku a je zřetelný i ve dnech neovlivněných kampaní. Např. ZŠ a MŠ Drahanovice začala další kolo hry s vyšším podílem udržitelných cest na cestách do školy než $v$ předchozím školním roce. ZŠ a MŠ Milíkov, ale také ZŠ Bedřicha Hrozného $v$ Lysé nad Labem zaznamenaly $v$ druhém kole kampaně tři týdny po hře vyšší podíl udržitelných cest na cestách do školy než v prvním kole hry, ačkoliv výchozí podíl udržitelných cest před kampaní byl ve druhém kole hry nižší.

\section{b) Počasí během hry}

Počasí ovlivňuje ochotu dětí a jejich rodičů používat udržitelné dopravní prostředky, především jízdní kolo. Pozitivní zpráva pro nás je, že kampaň s hadem Edou motivuje děti k cestování do školy udržitelnou dopravou do takové míry, že se stírá vliv počasí na cestování do školy udržitelným zpưsobem nebo automobilem - děti prostě "oblékají hada Edu", at' svítí slunce nebo prší.

Okamžitý stav počasí měl do jisté míry vliv na podíl udržitelných cest na cestách do školy před startem hry $(77,6 \%$ dětí takto cestovalo ve slunečné dny vs. $74,8 \%$ ve dnech, kdy bylo zataženo nebo deštivo). Slunečné počasí motivovalo více dětí $k$ chůzi a jízdě na kole do školy - o 5,6 procentních bodů více u chůze a 1,1 procentních bodů více u jízdy na kole než ve dnech, kdy bylo zataženo či deštivo. Naproti tomu během kampaně a 3 týdny po jejím ukončení vliv počasí klesá. Během kampaně je u chůze rozdíl mezi slunečnými

\footnotetext{
${ }^{7}$ Podrobnější výsledky - zastoupení jednotlivých druhů dopravy při cestách do školy - jsou dostupné online $v$ profilech jednotlivých škol zapojených do kampaně na internetové adrese:

http://www.trafficsnakegame.eu/czechrepublic/skoly/
} 
dny a dny, kdy je zataženo nebo deštivo, 2,6 procentních bodů a u jízdy na kole 0,3 procentních bodů. 3 týdny po kampani rozdíl klesá na 1,7 procentních bodů u chůze, zapojené školy dokonce vykázaly, že více dětí přijelo na kole ve dnech s horším počasím. ${ }^{8}$

Graf 4: Vliv počasí na dělbu prepravní práce $(v \%)$ u škol zapojených do hry v období $2014-2016$

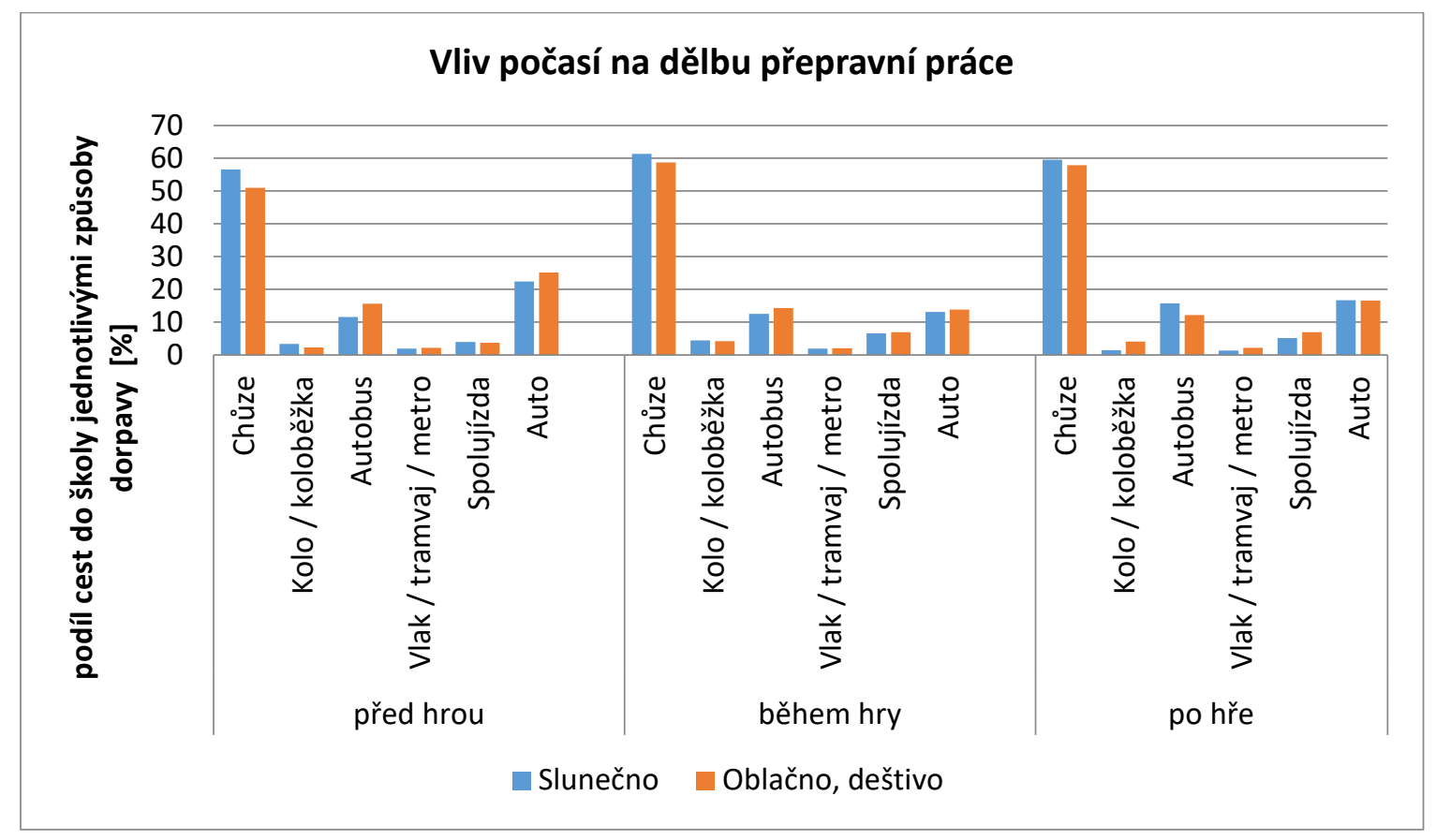

Zdroj: CDV, v.v.i. - Databáze kampaně „Oblékáme hada Edu" (neveřejná databáze výsledkü projektu)

\section{€) Dostupnost školy udržitelným způsobem dopravy, bezpeč- nost při cestách do školy a spolupráce s klíčovými aktéry v této oblasti}

Faktory dostupnosti školy udržitelným způsobem dopravy a dopravní bezpečnosti se prolínají a v dopravně exponovaných místech mají velký vliv na převažující způsob cestování dětí do školy (cesty osobním automobilem nebo udržitelným způsobem dopravy).

Několik př́kladů z výsledků kampaně k faktoru dostupnosti školy udržitelným způsobem a dopravní bezpečnosti při cestě do školy:

- ZŠ a MŠ Dobšice, leží v těsné blízkosti frekventované silnice I. třídy č. 53. Podle výsledků sčítání dopravy z roku 2010 tento úsek silnice spadá do intervalu 3001 -

\footnotetext{
8 Do kampaně se zapojily různě velké školy s odlišnými podmínkami pro alternativní druhy dopravy (nabídka a kvalita podpưrné infrastruktury, ochota rodičů ke změně dopravního chování apod.). Zdánlivý paradox, kdy větší podíl cest na kole je ve dnech s méně příznivým počasím (zataženo, deštivo) může být způsobem na našem vzorku škol také tím, že školy s větší motivací či lepšími podmínkami pro cyklodopravu realizovaly následný průzkum v období, kdy bylo zataženo či deštivo.
} 
5000 projíždějících vozidel za 24 hodin ${ }^{9}$. Škola realizovala hru "Oblékáme hada Edu“ $v$ záŕí 2016. Během hry se jí podařilo navýšit podíl udržitelných cest o 3 procentní body z původních $69 \%$ na $72 \%$.

- ZŠ a MŠ Košařiska, ZŠ a MŠ Milíkov - obě tyto venkovské školy jsou situovány $v$ dopravně klidných lokalitách, $v$ jejich okolí jsou jen místní komunikace s nízkou intenzitou automobilového provozu, a tím i poměrně bezpečné prostředí pro cestování do školy udržitelným způsobem. Oběma školám se podařilo během realizace kampaně na podzim 2016 výrazně zvýšit podíl udržitelných cest do školy (ZŠ a MŠ Košařiska o 29 procentních bodů a ZŠ a MŠ Milíkov o 28 procentních bodů). Velmi podobná situace byla i $v$ př́padě ZŠ a MŠ Křtiny, které se podařilo navýšit podíl udržitelných cest během kampaně o 22 procentních bodů. Obcí prochází silnice II. třídy s intenzitou provozu $1001-3000$ projíždějících vozidel za 24 hodin, škola však neleží v její těsné blízkosti.

$Z$ těchto př́padů je zřejmé, že $v$ lokalitách $s$ intenzivním automobilovým provozem je obtížnější měnit dopravní chování dětí. Do řešení bezpečnosti a dostupnosti škol udržitelnými způsoby dopravy je potřeba zapojit klíčové aktéry $v$ této oblasti. Vítaná je spolupráce zejména s místní samosprávou, ale také s veřejností, policií či zájmovými skupinami v oblasti dopravní bezpečnosti. Odborníci a místní samospráva mohou zajistit podpůrná opatření, např. zřízení nebo lepší zabezpečení přechodu pro chodce u školy, u zastávky MHD či implementaci opatření na snížení rychlosti aut - zóny 30, retardéry apod.

Osvědčilo se také spojení hry „Oblékáme hada Edu“ s projektem „Bezpečné cesty do školy“, kdy se mohly posílit pozitivní dopady obou akcí. Díky kampani s hadem Edou se posílila volba udržitelných dopravních prostředků a děti i rodiče mohli lépe reflektovat bezpečnostní situaci u školy a upozorňovat na problémy, které odrazují od chůze a použivání jízdního kola na cestách do školy. Projekt „Bezpečné cesty do školy" přinesl konkrétní dopravní úpravy ve spolupráci školy a městského úřadu, a posílil tak bezpečnost (i subjektivně vnímanou), a tím i ochotu nadále používat jízdní kolo, MHD či chodit pěšky.

Jak uvádí J. Heinrichová (2008), vozit dítě do školy autem je jen zdánlivě bezpečné. Dítě je $v$ autě jen pasivním účastníkem silničního provozu, naopak zkušenosti pro bezpečný pohyb v silničním provozu získává jen přímým kontaktem s každodenními problémy.

\section{d) Zapojení rodičů}

Právě podpora rodičů při cestách do školy udržitelnou dopravou je jeden z klíčových faktorů úspěchu kampaně, zejména u menších dětí. Dokud rodiče nebudou mít pocit, že jsou jejich děti při chůzi, jízdě na kole nebo cestě z / do školy ze zastávky veřejné dopravy $v$ bezpečí a nepodpoří děti ve větším využivání těchto udržitelných druhů dopravy, nemůže být změna dopravního chování možná a už vůbec ne dlouhodobá. I z tohoto pohledu je důležitá realizace podpůrných opatření, zejména zajištění bezpečného prostředí pro alternativní způsoby dopravy do školy.

\section{Srovnání ČR se zahraničím}

Ve srovnání s ostatními zeměmi zapojenými do kampaně TSG je $v$ ČR vyšší podíl udržitelných cest do školy již před startem hry. ČR patřila ve školním roce 2015/2016 k

${ }^{9}$ Zdroj: ŘSD, viz http://scitani2010.rsd.cz 
zemím s největším podílem chůze a naopak nejmenším využitím individuální automobilové dopravy (IAD) při cestách do školy během konání kampaně. Menší podíl IAD při cestách do Školy než ČR měly z 19 zapojených zemí pouze Rakousko, Německo a Mad'arsko.

Naopak nárůst podílu udržitelných cest $v$ průběhu hry není v ČR tak výrazný jako $\checkmark$ prípadě některých jiných evropských zemí (Bulharsko, Německo či Řecko). Ve srovnání se Slovenskem byl v ČR vyšší podíl udržitelných cest do školy již před startem hry, nárůst podílu těchto cest byl srovnatelný v obou zemích (o 10-11 procentních bodů). Na Slovensku je i obdobný dlouhodobější vliv kampaně na změnu dopravního chování dětí. $V$ ČR činil ve školním roce $2014 / 2015$ podíl udržitelných cest do školy tři týdny po konci hry $81 \%$, na Slovensku $82 \%$. Ve školním roce 2015/2016 činil podíl udržitelných cest v českých školách zapojených do hry $82 \%$ a na Slovensku 84 \%. Podrobnější data přináší evaluační zprávy kampaně TSG ${ }^{10}$.

\section{Závěr}

Hra "Oblékáme hada Edu" zábavnou formou motivuje děti ke změně dopravního chování. Její formát umožňuje ji zapojit do různých předmětů a aktivit školy, přináší prostor pro školy i pedagogy pro vlastní přístup a inovaci.

Co hra „Oblékáme hada Edu“ v ČR dosud (od roku 2014) přinesla?

- Snížení emisí skleníkových plynů z dopravy o 11 tun ekvivalentu $\mathrm{CO}_{2}$ oproti situaci, když by se dopravní chování dětí nezměnilo a bylo stejné jako za výchozích podmínek ( $v$ den průzkumu před hrou). Úspora emisí $\mathrm{CO}_{2}$ byla spočítána na základě ušetřených kilometrů cest automobilem pomocí evaluačního nástroje MaxEVA (viz pozn. pod čarou 4)

- Pokles množství automobilů přivážejících ráno děti do školy o $40 \%$ oproti původní situaci pred startem hry (cesty dětí individuálně autem s rodiči).

- Zvýšení podílu aktivní dopravy do školy (chůze a jízda na kole či koloběžce) $v$ průměru o 10 procentních bodů.

- Děti se i v chladných měsících roku navzájem motivují, kdo přijde další den pěšky, přijede na kole, MHD nebo vezme kamaráda s sebou do školy autem.

- Zavedení dalších opatření na zvýšení bezpečnosti a podporu udržitelné dopravy u některých škol ve spolupráci s městem (zřízení zóny $K+R$ u komplexu škol v Lysé nad Labem, zajištění stojanů na kola u některých škol, např. u ZŠ a MŠ Otnice).

- Město Opava využije data z kampaně o způsobech dopravy dětí do školy při aktualizaci svého Plánu udržitelné městské mobility.

Tato kampaň nabízí vynikající příležitost k zavedení opatření orientovaných na dopravní politiku, ze kterých mohou profitovat školy i jejich místní komunity, potažmo celé město. Doporučujeme vždy spolupráci s daným městským úřadem, který může být i v roli koordinátora kampaně, ale především je orgánem, který rozhoduje o realizaci mnoha užitečných opatření, která usnadňují a podporují cesty do škol udržitelnými druhy dopravy.

\footnotetext{
${ }^{10}$ Evaluační zprávy za jednotlivé školní roky jsou k dispozici na webových stránkách projektu: http://www.trafficsnakegame.eu
} 
Hra bezprostředně zasahuje také do ranních cest rodičů, kteří doprovází děti do školy a kteří jsou prostřednictvím svých dětí motivováni změnit své dopravní chování. To může $v$ některých prípadech narážet na odpor ze strany rodičů, proto je dobré zhodnotit místní dopravní situaci a možnosti a nabídnout také alternativu pro ranní cesty do školy udržitelnou dopravou. Možností jsou napríklad tzv. pěší busy či cyklobusy, tedy skupinky dětí ze sousedství přepravující se do školy společně pod vedením dospělého.

Aby mohla být změna volby dopravního prostředku dlouhodobá, je však důležité zajistit bezpečnost dětí, zejména $v$ dopravně exponovaných místech. Je proto vhodné tuto kampaň začlenit do balíčku opatření řešících komplexně koncepci udržitelné dopravy $v$ daném městě nebo lokalitě. Osvědčilo se také propojení s projektem „Bezpečné cesty do školy“, v rámci kterého děti vytipují nebezpečná místa při své cestě do školy a ve spolupráci s místní samosprávou a dopravními projektanty jsou realizována opatření pro zvýšení bezpečnosti dětí v těchto místech.

\section{Poděkování}

V článku byly použity data a výsledky projektu Traffic Snake Game. Článek byl vytvořen za finanční podpory Ministerstva školství, mládeže a tělovýchovy v rámci programu dlouhodobého koncepčního rozvoje výzkumných organizací na výzkumné infrastruktuře pořízené $z$ Operačního programu Výzkum a vývoj pro inovace (CZ.1.05/2.1.00/03.0064).

\section{Literatura}

- Carver, A., Timperio, A.F., Hesketh, K.D., Ridgers, N.D., Salmon, J.L., \& Crawford, D.A. (2011). How is active transport associated with children's and adolescents' physical activity over time? International J ournal of Behavioral Nutrition and Physical Activity 2011, 8, 126. DOI: 10.1186/1479-5868-8-126

- CDV (2015). Manuál pro učitele. Jak organizovat hru "Oblékáme hada Edu" ve vaší škole. Dostupné na http://www.trafficsnakegame.eu/czechrepublic/wpcontent/uploads/sites/7/Manual-pro-ucitele_2015.pdf

- Heinrichová, J. (2008). Bezpečná cesta do školy. Envigogika 2008, 3, 1. DOI: http://dx.doi.org/10.14712/18023061.286

- McDonald, N.C. (2005). Children's Travel: Patterns and Influences. UC Berkeley: University of California Transportation Center. Retrieved from: http://escholarship.org/uc/item/51c9m01c

- MŠMT (2016). Rámcový vzdělávací program pro základní vzdělávání. Ministerstvo školství, mládeže a těchovýchovy ČR. Dostupné na http://www.nuv.cz/uploads/RVP_ZV_2016.pdf

- Percer, J. (2009). Child Pedestrian Safety Education: Applying Learning and Developmental Theories to Develop Safe Street-Crossing Behaviors. U.S. Department of Transportation. Dostupné na https://www.nhtsa.gov/sites/nhtsa.dot.gov/files/811190.pdf 
- Pooley, C.G., Turnbull, J., \& Adams, M. (2005). The journey to school in Britain since the 1940s: continuity and change. Area, 37, 43-53. doi:10.1111/j.14754762.2005.00605.x

- Raitakari, O., Porkka, K., Viikari, J., Ronnemaa, T., \& Akerblom, H. (1994). Clustering of risk factors for coronary heart disease in children and adolescents. The Cardiovascular Risk in Young Finns Study. Acta Pædiatrica, 83, 935-940.

DOI: 10.1111/j.1651-2227.1994.tb13176.x

- Schwebel, D.C., Davis, A.L., \& O’ Neal, E.E. (2012). Child Pedestrian Injury: A Review of Behavioral Risks and Preventive Strategies. American J ournal of Lifestyle Medicine, 6(4), 292-302. DOI: 10.1177/0885066611404876

- Shaw, B., Watson, B., Frauendienst, B., Redecker, A., J ones, T., \& Hillman, M. (2013). Children's independent mobility: a comparative study in England and Germany (1971-2010). London: Policy Studies Institute. Dostupné na http://www. reesjeffreys.co.uk/wp-content/uploads/2010/10/CIM-Final-report1.pdf

- Verhetsel, A., \& Witlox, F. (2006). Children and Housing: 'Only the Best is Good Enough'. Childhood, 13(2), 205-224. DOI:10.1177/0907568206062929

- Zwerts, E., Allaert, G., Janssens, D., Wets, G., \& Witlox, F. (2010). How children view their travel behaviour: a case study from Flanders (Belgium). J ournal of Transport Geography, 18, 702-710. DOI:10.1016/j.jtrangeo.2009.10.002

- Zeedyk, M. S., \& Wallace, L. (2003). Tackling children's road safety through edutainment: an evaluation of effectiveness. Health Education Research: Theory \& Practice, 18(4), 493-505. DOI: 10.1093/her/cyf033

Mgr. Danuše Strnadová, výzkumná pracovnice v oblasti dopravního vzdělávání, Centrum dopravního výzkumu, v.v.i., Líšeňská 33a, Brno. Email: danuse.strnadova@cdv.cz

Ing. Mgr. Hana Brůhová Foltýnová, PhD., výzkumná pracovnice v oblasti dopravní a environmentální ekonomie, Kolínský technologický institut, z.s., Okružní 703, Kolín. Email: bruhova@koltech.cz

Mgr. Radomíra Jordová, výzkumná pracovnice v oblasti dopravního plánování, Centrum dopravního výzkumu, v.v.i., Líšeňská 33a, Brno. Email: radomira.jordova@cdv.cz 